During his retirement he enjoyed gardening, especially growing roses, impatiens, and coleus and serving as a teacher's aid for his daughters, who became school teachers.

\title{
Peter Semeniuk
}

Peter Semeniuk died 21 Sept. 2004. He is survived by his wife Bernadette J. Semeniuk and daughters JosephineA. Pesi, Mary F. Kirchner, and Ann M. Patterson. Pete was born 17 April 1921 in Baltimore, Md. He received his BS and MS from the University of Maryland, College Park. Pete enlisted in the army during World War II and was a private 1st Class in Company B 3rd Parachute Training Regiment. He was injured during the war while being transported within the U.S. and received an honorable discharge as a disabled veteran.

After the war, Pete came to work at the USDA-ARS in Beltsville, Md. He worked at the USDA for 37 years as a plant breeder. Pete was known for breeding pollution-tolerant Coleus; Clown series of dwarf compact Torrenia; and Troll series of dwarf compact Browallia. Pete, along with Rob Griesbach and Mark Roh, developed tissue-culture procedures for Eustoma that were used to create somaclonal variants for plant habitat. These variants were to develop the first dwarf pot type ('Little Belle Blue'). Pete was also involved in developing cryopreservation methods for storing rose blackspot spores. He, along with John Palmer, developed a detached-leaf assay that would allow resistance evaluation on different rose species and varieties using a standard source of rose blackspot inoculum. This research led to development of the Spotless series of blackspot resistant garden Rosa.

During his career, Pete participated in many ASHS annual meetings. He was also a devoted member of the Ornamental Plant Breeding Working Group. 